\title{
Growth, nutrient digestibility, ileal digesta viscosity and energy metabolizability of growing turkeys fed diets containing malted sorghum sprouts supplemented with enzyme or yeast
}

by Oke, F.O., Oso, A.O., Odugwa,O.O., Jegede,A.V., Südekum,K.H., Fafiolu, A.O., Pirgozliev, V.

Copyright, Publisher and Additional Information: This is the author accepted manuscript. The final published version (version of record) is available online via Wiley.

Please refer to any applicable terms of use of the publisher.

DOI: $10.1111 /$ jpn.12597

Harper Adams

University

Oke, F.O., Oso, A.O., Odugwa,O.O., Jegede,A.V., Südekum,K.H., Fafiolu, A.O., Pirgozliev, V. 2016. Growth, nutrient digestibility, ileal digesta viscosity, and energy metabolizability of growing turkeys fed diets containing malted sorghum sprouts supplemented with enzyme or yeast. Journal of Animal Physiology and Animal Nutrition 
1 Growth, nutrient digestibility, ileal digesta viscosity and energy metabolisability of growing

2 turkeys fed diets containing malted sorghum sprouts supplemented with enzyme or yeast

3 F. O. $\mathrm{Oke}^{1}$, A. O. Oso ${ }^{2}$, O. O. Oduguwa ${ }^{2}$, A. V. Jegede ${ }^{2}$, K-H. Südekum ${ }^{3}$, A. O. Fafiolu ${ }^{2}$ and V.

$4 \quad$ Pirgozliev $^{4}$

$5 \quad{ }^{1}$ Federal University Dutse, P.M.B. 7156 Dutse Jigawa State, Nigeria, ${ }^{2}$ College of Animal Science 6 and Livestock Production, Federal University of Agriculture Abeokuta, P.M.B. 2240. Abeokuta,

7 Nigeria, ${ }^{3}$ University of Bonn, Institute of Animal Science, Endenicher Allee 15, 53115 Bonn,

8 Germany, ${ }^{4}$ Harper Adams University, Newport Shropshire TF10 8NB United Kingdom

*Correspondence to: Dr F.O. Oke, Federal University Dutse, P.M.B. 7156 Dutse Jigawa State,

11 Nigeria. West Africa Tel.: +234 08036316394; E mail: florenceobadire@ gmail.com (F.O. Oke).

13 Running head: Turkeys fed with malted sorghum sprouts

15 Summary

16 Growth, apparent nutrient digestibility, ileal digesta viscosity and energy metabolisability of

17 growing turkeys fed diets containing malted sorghum sprouts (MSP) supplemented with enzyme

18 or yeast was investigated using 120, 28-days old, male turkeys. There were six treatments laid

19 out in a $3 \times 2$ factorial arrangement of treatments having three dietary inclusion levels of MSP

$20(0,50$ and $100 \mathrm{~g} / \mathrm{kg})$ supplemented with or without $200 \mathrm{mg} / \mathrm{kg}$ of a commercial enzyme. The 
21 experiment lasted for the starter (day 28-56) and grower phases (day 57-84) of the birds. Each

22 treatment group consisted of 20 turkeys replicated 4 times with 5 birds each. Data were analysed

23 using analysis of variance while polynomial contrast was used to determine the trends (linear and

24 quadratic) of MSP inclusion levels. Irrespective of dietary supplementation with enzyme or

25 yeast, final live weight, total weight gain and feed intake for turkey poults from day 29-56

26 reduced $(\mathrm{P}<0.05)$ with increasing inclusion level of MSP. Dietary supplementation with yeast

27 resulted in increased $(\mathrm{P}<0.05)$ feed intake while enzyme supplementation improved $(\mathrm{P}<0.05)$

28 feed conversion ratio of the poults. Starter and grower turkeys fed enzyme-supplemented MSP

29 diets had higher $(\mathrm{P}<0.05)$ weight gain than their counterparts fed yeast-supplemented MSP

30 diets. Apparent ash digestibility reduced linearly $(\mathrm{P}<0.05)$ with increasing inclusion levels of

31 MSP. Apparent metabolisable energy (AME) did not vary significantly ( $\mathrm{P}>0.05$ ) with MSP

32 inclusion levels. Dietary inclusion of $100 \mathrm{~g} / \mathrm{kg}$ MSP recorded the highest $(\mathrm{P}<0.05)$ ileal digesta

33 viscosity. Enzyme supplementation reduced $(\mathrm{P}<0.05)$ ileal viscosity but had no effect $(\mathrm{P}>0.05)$

34 on AME. Inclusion of MSP resulted in poor growth performance. This confirms reports of earlier

35 studies that utilization of MSP by poultry is rather poor. Supplementation with enzyme or yeast

36 did not lead to any appreciable improvement in performance of turkeys in this study.

37 Keywords: Turkey poults, ileal digesta viscosity, malted sorghum sprouts, yeast, energy 38 metabolisability. 


\section{Introduction}

44 Feed cost required in commercial poultry production has risen astronomically due to the

45 competition between man, livestock and agro-industries for the limited cereal grains available

46 (Oso et al., 2010). This food-feed pressure especially in the developing countries necessitated the

47 search for alternative feed stuffs which are cheap and readily available.

48 Malted sorghum sprouts (MSP) produced as a result of incomplete germination of sorghum

49 (referred to as malting) is a cheap alternative feedstuff. This malting process is commonly used

50 in breweries and food processing companies for the manufacture of drinks, beverages, etc.

51 (Briggs et al., 1991). The residue remaining after the extraction of malt from the germinated

52 cereal seed is referred to as 'malted sorghum sprouts' (MSP) (Oduguwa et al., 2001).

53 Commercial malting of sorghum with an output estimated to the tune of 200000 metric tons of

54 malted and unmalted extracts per annum was reported by Ikediobi (1989). This has led to the

55 production of large quantities of MSP.

56 Nutritional evaluation of MSP showed that it contained 226, 224, 33 and $522 \mathrm{~g} / \mathrm{kg}$ (DM basis) of

57 crude protein, neutral detergent fibre, ether extract and nitrogen free extract, respectively (Aning

58 et al., 1998). Oke (2010) reported a crude protein, ether extract, ash, NDF, ADF and ADL values

59 of $163.7,38.2,62.70,217,147,10.3 \mathrm{~g} / \mathrm{kg}$, respectively for MSP. Successful utilization of MSP

60 up to $10 \%$ inclusion in growing pullets has been reported in previous studies (Fafiolu et al.,

61 2006). However, the nutritional potentials of MSP as feedstuff for poultry are limited due to the

62 constituent fibre fractions (NDF and ADF), hydrocyanide and tannin contents (Oduguwa et al.,

63 2001). Residues of tannin and arabinoxylan have been reported to reduce nutrient digestibility

64 and growth of poultry (Balogun et al., 2005). Recent studies have shown that dietary

65 supplementation with fibre degrading enzymes improved ileal nitrogen retention, apparent 
66 metabolisable energy (AME) (Cowieson et al., 2003), digestion of dietary starch, fibre, protein

67 and lipid in poultry (Choct et al., 1999). Similarly, yeast and its extracts have been reported to

68 improve growth, nutrient digestibility and stimulate birds' immune systems (Abel and Czop,

69 1992). In this present study, diets containing 0, 50, or $100 \mathrm{~g} / \mathrm{kg}$ MSP in which supplements of

70 either enzyme or yeast have been incorporated were fed to growing turkeys. The performance

71 characteristics, nutrient digestibility, viscosity of ileal digesta and energy metabolisability were

72 used as criteria of response.

\section{Materials and methods}

\section{Source and chemical composition of malted sorghum sprouts}

76 Malted sorghum sprouts (MSP) was obtained commercially from a local brewery industry in

77 Ogun State, Nigeria. This was dried (10-11\% moisture content) prior to collection and included

78 on DM basis in the experimental diets. Proximate composition (AOAC, 1990), fibre fractions

79 (Van Soest et al., 1991), gross energy (Adiabatic bomb calorimeter, Parr Instrument Company,

80 Moline, IL, USA) and tannin content (Hoff and Singleton, 1977) of MSP was determined

81 according to standard procedures (Table 1). For $\mathrm{Ca}$ and $\mathrm{P}$ determination of MSP, samples were

82 further dried in a hot air oven $\left(105^{\circ} \mathrm{C}\right.$ for $\left.8 \mathrm{~h}\right)$, milled to pass through $0.5 \mathrm{~mm}$ sieve and ignited

83 at $400{ }^{\circ} \mathrm{C}$ for $4 \mathrm{~h}$ in a muffle furnace. The ash was treated with $\mathrm{HNO}_{3}$ under mild heat $\left(80{ }^{\circ} \mathrm{C}\right)$

84 and digested $\left(15 \mathrm{ml} \mathrm{HNO}_{3}\right)$. Analysis was done using the atomic absorption spectrophotometer

85 (Perkin Elmer Optima 4300DV ICP spectrophotometer, Beaconsfield, UK). 


\section{Enzyme and yeast}

89 The commercial enzyme used in this study is a blend of enzymes consisting of endo $-1,4-\beta-$

90 xylanase (EC 3.2.1.8), endo - 1, 3 (4) - $\beta-$ glucanase (EC 3.2.1.6) and endo $-1,4-\beta-$

91 glucanase (EC 3.2.1.4) produced by Trichoderma reesei. Baker's yeast was purchased

92 commercially.

\section{Experimental birds and management}

94 One hundred and fifty, 1 day-old, male British United turkeys (BUT) were purchased from a 95 commercial hatchery. Brooding (day 0 to 28) was done intensively in a deep litter housing 96 system during which all the birds were fed with a pre-starter turkey ration (Table 2). During this

97 time, temperature was controlled at $34.5^{\circ} \mathrm{C}$ for the first 2 days and then gradually reduced by $2^{\circ} \mathrm{C}$ 98 per week to a final ambient temperature of $27^{\circ} \mathrm{C}$ in the last week of brooding. Feed and clean 99 water were supplied ad libitum. Normal vaccination program and medication schedule were 100 strictly adhered to.

\section{Dietary treatments}

102 At day 28, 120 male turkeys of similar weight were selected from the flock above and assigned

103 on weight equalization basis to six dietary treatments laid out in a $3 \times 2$ factorial arrangement of 104 treatments having three dietary inclusion levels of MSP (i.e. 0, 50 and $100 \mathrm{~g} / \mathrm{kg}$ ) supplemented 105 with either $200 \mathrm{mg} / \mathrm{kg}$ commercial enzyme or $200 \mathrm{mg} / \mathrm{kg}$ yeast for day 29 to 56 (starter phase) 106 and day 57 to 84 (grower phase), respectively (Table 2). Each treatment group consisted of 20 107 turkeys replicated four times with 5 birds each. 
111 Feed intake was computed as the difference between the feed offered and leftovers. Gain in

112 weights and feed intake were measured at weekly intervals. Feed to gain ratio was computed as

113 the ratio of feed consumed to weight gain. No mortality occurred during the study

\section{Metabolic trial}

116 Metabolic trial was conducted from day 77 to 84 of the study to determine the apparent nutrient

117 digestibility and metabolisable energy values. Briefly, 2 birds per replicate $(\mathrm{n}=8$ per treatment)

118 were randomly selected and housed separately in appropriate metabolic cages fitted with 119 individual feed troughs and facility for separate excreta collection. The birds were acclimatized

120 for 2 days prior to the commencement of 4 days metabolic trial. Excreta collected per bird per 121 day (for 4 days) were oven dried $\left(60^{\circ} \mathrm{C}\right)$ and used for analysis. Proximate compositions of feed 122 and dried excreta samples were determined according to standard procedures (AOAC, 1990).

123 The birds on metabolic trial were still used as part of the performance because their feed intake 124 and weight during the metabolic trial were noted and computed along with performance data

125 Gross energy determination of excreta samples was carried out (Adiabatic bomb calorimeter, 126 Parr Instrument Company, Moline, IL, USA). The equation below was used to calculate apparent 127 metabolizable energy (AME), as described by Sibbald (1989):

128

129

130

$$
\text { AME }(\mathrm{MJ} / \mathrm{Kg} \mathrm{DM})=\left[\frac{(\mathrm{Fi} \times \mathrm{GEf})-(E \times \mathrm{GEe})]}{\mathrm{Fi}}\right.
$$$$
\mathrm{Fi}
$$

Where Fi is the feed intake (g), E is excreta output (g), GEf is the gross energy (MJ/ kg) of feed, GEe the gross energy (MJ/ kg) of excreta. 


\section{Viscosity of ileal digesta}

134 A bird was randomly selected from each replicate $(n=4$ birds per treatment $)$ and slaughtered at 135 day 84 for the determination of viscosity of ileal digesta. The gastro-intestinal tract was dissected 136 aseptically immediately after slaughter and the intestinal content was exposed. The ileal digesta 137 content was collected from the Merckel's diverticulum to the ileocaecal junction. Uniform 138 weights of the samples ( $5 \mathrm{~g}$ ) were taken from each bird using a sensitive scale and diluted to a 139 volume of $400 \mathrm{ml}$. The ileal contents collected were centrifuged at $6000 \mathrm{rpm}$ for 20 minutes. The 140 supernatant was withdrawn and the viscosity (expressed as milli-Pascal seconds mPas) was 141 measured using a viscometer (Brookfield digital DV-II+, Brookfield Engineering Labs, 142 Stoughton, U.K.) while values were recorded at a shear rate of $45 \mathrm{~s}^{-1}$.

\section{Statistical analysis}

144 Data obtained were analyzed by the general linear model of the SAS (SAS Institute, 2003). 145 Polynomial contrast (linear and quadratic) was also applied using SPSS (1999) to determine the 146 trends (linear and quadratic) of inclusion levels $(0,50$ and $100 \mathrm{~g} / \mathrm{kg})$ of MSP. A probability of $P$ $147<0.05$ was considered to be statistically significant.

149 Results

150 The chemical composition of MSP as shown in Table 1 reveals a high NDF and ADF (217 151 and147 g/kg respectively), fairly low ADL (10.3 g/kg), low Ca $(9.2 \mathrm{~g} / \mathrm{kg})$ and extractible tannin 152 content $(0.09 \mathrm{mg} / \mathrm{kg})$. The $\mathrm{HCN}$ value is $3.02 \mathrm{mg} / \mathrm{kg}$. It has low gross energy $(14.9 \mathrm{MJ} / \mathrm{kg})$ and 153 moderately fibrous (107.50 g/kg crude fibre). 
155 Main effects of MSP inclusion and supplementation with enzyme or yeast on growth 156 performance of turkeys

157 The final live weight, weight gain and feed intake of the starter turkey poults (day 29 to 56) 158 reduced (Linear, $\mathrm{P}<0.01$, Quadratic, $\mathrm{P}<0.0001)$ with increasing dietary inclusion levels of 159 MSP (Table 3). However, dietary supplementation with enzyme reduced $(\mathrm{P}<0.05)$ feed intake 160 and improved $(\mathrm{P}<0.05)$ feed conversion ratio of turkey poults.

161 Final live weight and total feed intake of grower turkeys (day 57 to 84$)$ decreased $(\mathrm{P}<0.01)$ with

162 increasing inclusion levels of MSP. All grower turkeys fed diet containing MSP (irrespective of 163 inclusion levels) had reduced $(\mathrm{P}<0.01)$ weight gain compared to those fed diet containing no 164 MSP. Enzyme supplementation improved $(\mathrm{P}<0.05)$ the final live weight and total weight gain 165 while supplementation with yeast increased $(\mathrm{P}<0.05)$ total feed intake.

167 Interaction effects of MSP inclusion and supplementation with enzyme or yeast on growth 168 performance of turkeys

169 Irrespective of dietary supplementation with enzyme or yeast, final live weight, total weight gain 170 and feed intake of the turkey poults reduced $(\mathrm{P}<0.05)$ with increasing MSP inclusion (Table 4).

171 Turkey poults fed enzyme-supplemented diets containing $100 \mathrm{~g} / \mathrm{kg}$ MSP had better $(\mathrm{P}<0.05)$ 172 weight gain than their counterparts fed with $100 \mathrm{~g} / \mathrm{kg}$ MSP supplemented with yeast. 173 Supplementation of MSP based diets with yeast resulted in increased $(\mathrm{P}<0.05)$ feed intake while 174 enzyme supplementation of MSP based diets showed improved $(\mathrm{P}<0.05)$ feed conversion ratios.

176 At the grower phase, final live weight and feed intake reduced $(\mathrm{P}<0.05)$ with increasing 177 inclusion levels of MSP with enzyme or yeast supplementation (Table 3). Grower turkeys fed 
178 diets containing no MSP had the highest $(\mathrm{P}<0.05)$ final live weight, total weight gain and feed

179 intake. Grower turkeys fed diets containing $50 \mathrm{~g} / \mathrm{kg}$ MSP supplemented with yeast had the least

$180(\mathrm{P}<0.05)$ total weight gain. Supplementation of MSP diets with enzyme resulted in higher $(\mathrm{P}<$

181 0.05) final live weight and weight gain than their counterparts fed yeast-supplemented MSP

182 diets.

183 Main effects of MSP inclusion and dietary supplementation with enzyme or yeast on 184 apparent nutrient digestibility, metabolizable energy value and intestinal viscosity

185 Turkeys fed diets containing $100 \mathrm{~g} / \mathrm{kg}$ MSP recorded the highest $(\mathrm{P}<0.05)$ apparent dry matter 186 digestibility while those fed diets containing 0 and $50 \mathrm{~g} / \mathrm{kg} \mathrm{MSP}$ had the least $(\mathrm{P}<0.05)$ dry 187 matter digestibility values. (Table 5) Ash retention reduced linearly $(\mathrm{P}<0.05)$ with increasing 188 inclusion levels of MSP.

189 Turkeys fed diets containing varying inclusion levels of MSP had no significant effect $(\mathrm{P}>0.05)$ 190 on AME values neither was the enzyme supplementation also. Highest viscosity of ileal digesta 191 was obtained with turkeys fed diets containing $100 \mathrm{~g} / \mathrm{kg}$ MSP. Dietary supplementation with 192 enzyme reduced $(\mathrm{P}<0.05)$ viscosity of ileal digesta.

194 Interaction effect of MSP inclusion and dietary supplementation with enzyme or yeast on 195 apparent nutrient digestibility, metabolisable energy values and intestinal viscosity

196 Turkeys fed diet containing $100 \mathrm{~g} / \mathrm{kg}$ MSP supplemented with enzyme had the highest $(\mathrm{P}<0.05)$ 197 apparent dry matter digestibility while those fed diets containing 0 and $50 \mathrm{~g} / \mathrm{kg}$ MSP 198 supplemented with enzyme or yeast recorded the least $(\mathrm{P}<0.05)$ values $($ Table 6). Turkeys fed 199 diets containing no MSP supplemented with enzyme recorded the least $(\mathrm{P}<0.05)$ viscosity of 
200 ileal digesta. High $(\mathrm{P}<0.05)$ viscosity of ileal digesta values were obtained for turkeys fed diets

201 containing MSP supplemented with either enzyme or yeast.

\section{Discussion}

205 Reduced feed intake of turkeys obtained with increasing dietary inclusion of MSP could be 206 attributed to the gritty nature of MSP. Previous studies attested to the fact that MSP is quite gritty 207 with a variable crude fibre content ranging between 80 to $170 \mathrm{~g} / \mathrm{kg}$ of dry matter and NDF of 224 $208 \mathrm{~g} / \mathrm{kg}$ (DM basis) depending on the processing methods employed (Akinola, 2002). Poultry has

209 been reported to be poor digester of fibre (Longe and Ogedengbe, 1989).

210 The reduced growth of turkeys obtained in the current study following increasing inclusion 211 levels of MSP agreed with previous studies (Oduguwa et al., 2007). The observed poor growth 212 could also be attributed to the presence of some deleterious factors contained in MSP which

213 limits its utilization. MSP used in the current study contain $3.02 \mathrm{~g} / \mathrm{kg} \mathrm{HCN}$ content. Dietary HCN

214 when fed to birds forms a complex with Fe in the heamoglobin to form cynahaemoglobin (Hb215 CN) resulting in reduced mean oxygen carrying capacity of the blood (Cardoso et al., 2005). 216 Although, the extractible tannin content of MSP in the current study is low, MSP was reported to 217 contain high content of tannins bound with fibre which were not extractible but had potential to 218 inhibit digestive enzymes and reduced nutrient digestibility (Mariscal- Landin et al., 2004). 219 Oduguwa et al. (2007) reported that MSP contained indigestible fibre which increased ileal 220 viscosity and depressed nutrient digestibility.

221 Enzyme supplementation of MSP diets in the current study showed a slight improvement in feed 222 conversion ratio of young turkey poults, final liveweight and weight gain of growing turkeys. 
223 Previous studies with broilers also reported improved performance when similar enzyme was

224 supplemented in MSP diets (Oke, 2010). Supplementation with fibre-degrading enzymes had

225 been reported to increase weight gain, improve feed conversion and protein digestibility of

226 poultry birds (Café et al., 2002).

227 Higher feed intake obtained for turkey poults and growing turkeys in this study following dietary 228 supplementation with yeast compared to enzyme supplementation corroborated previous findings 229 that feed intake and feed efficiency improved following dietary inclusion of yeast (Parks et al., 230 2001). These beneficial effects following inclusion of yeast have been linked with increased 231 digestive enzyme activity (Zhang et al., 2005) stimulated by the $\beta-1,3, \beta-1,6$ glycosidic 232 linkages present in yeast which stimulated immune modulator substances in animals (Parks et 233 al., 2001).

234 The high apparent dry matter digestibility obtained with turkeys fed an enzyme-supplemented 235 diet containing $100 \mathrm{~g} / \mathrm{kg}$ MSP showed possible improvement in the utilization of MSP when 236 supplemented with fibre degrading enzymes. Improvement in the nutrient digestibility of 237 erstwhile denigrated feedstuffs when supplemented with enzyme has been reported (Zyla et al., 238 2000). The trend of this study also supported earlier findings which reported improved 239 digestibility coefficient following dietary supplementation with an enzyme (Cowieson et al., 240 2003).

241 High viscosity of ileal digesta obtained with growing turkeys fed MSP diets supplemented with 242 yeast and those fed diets containing $100 \mathrm{~g} / \mathrm{kg}$ MSP supplemented with enzyme implied an 243 adverse effect of MSP inclusion. Previous studies have shown that the higher the viscosity of the 244 ileal digesta the lesser the AME values (Petersen et al., 1999). Increasing intestinal viscosity of 245 poultry birds have been reported to result in poor feed conversion ratio (Bedford, 2000). 
246 Reduced intestinal viscosity obtained with turkeys fed diets containing $50 \mathrm{~g} / \mathrm{kg}$ MSP

247 supplemented with enzyme corroborated their apparent improved growth response. The

248 reduction in viscosity within the gastro-intestinal tract caused by enzyme supplementation has

249 been linked with bile salt production and de-conjugation influencing nutrient uptake and dietary

250 metabolizable energy values, a mechanism which could lead to improved nutrient uptake and

251 animal performance (Choct et al., 1989). Yeast supplementation, however, did not reduce 252 intestinal viscosity of turkeys in this study.

253 In conclusion, dietary inclusion level of malted sorghum sprouts with or without yeast or enzyme 254 supplementation resulted in poor growth performance and increased viscosity of ileal digesta of 255 turkeys. Higher dosage of enzyme supplementation or use of more specific enzyme mixture is 256 suggested in further studies since the improvement in performance following enzyme 257 supplementation was not appreciable.

259 References

260 Abel, G.; Czop, J. K., 1992: Stimulation of human monocyte-glucan receptors by glucan 261 particles induces production of TNF- and IL-1. International Journal of 262 Immunopharmacology 14, 1363-1373.

263 Akinola, O. A., 2002: Effect of alkaline treated MSP and untreated MSP on broilers. Masters of 264 Science Thesis Dissertation, Submitted to the Department of Animal Nutrition. Federal 265 University of Agriculture, Abeokuta, Nigeria.

266 Aning, K. G.; Ologun, A. G.; Onifade, A.; Alokan, J. A.; Adekola, A. I.; Aletor, V.A., 1998:

267 Effect of replacing dried brewer's grain with sorghum rootlets on growth, nutrient 
utilization and some blood constituents in the rat. Animal Feed Science and Technology 71, 185-190.

270

271

272

273

274

275

276

277

278

279

280

281

282

283

284

285

286

287

288

AOAC., 1990: Association of Official Analysis Chemistry, Official Methods of Analyses, $15^{\text {th }}$ edition., AOAC, Arilington, Virginia.

Balogun, R. O.; Rowe, J. B.; Bird, S. H., 2005: Fermentability and degradability of sorghum grain following soaking, aerobic or anaerobic treatment. Animal Feed Science and Technology 120, 141-150.

Bedford, M. R., 2000: Mechanism of action and potential benefit from the use of feed enzymes. Animal Feed Science and Technology 53, 145-155.

Briggs, D. E.; Hough, J. S.; Sterens, R.; Young, F. W., 1991: Malting and brewing science. Volume 1, $2^{\text {nd }}$ Edn. London, Chapman and Hall Publisher.

Café, M. B.; Borges, C. A.; Fritis, C.; Waldroup, P.W., 2002: Avizyme improves performance of broilers fed corn-soybean meal-based diets. Journal of Applied Poultry Research 11, 2033.

Choct, M.; Hughes, R. J.; Wang, M. R.; Bedford, A.J.; Morgan, J., 1996: Increased small intestinal fermentation is partly responsible for the anti-nutritive activity of non-starch polysaccharides in chickens. British Poultry Science 37, 609-621.

Cowieson, A.J.; Acamovic, T.; Bedford, M.R., 2003: Supplementation of diets containing pea meal with exogenous enzymes: Effects on weight gain, feed conversion, nutrient digestibility and gross morphology of the gastrointestinal tract of growing broiler chicks. British Poultry Science 44, 427-437. 
Fafiolu, A. O.; Oduguwa, O.O.; Ikeobi, C.O.N.; Onwuka, C.F.I., 2006: Utilization of malted sorghum sprouts in the diet of rearing pullets and laying hens. Archivos de Zootechina 55, 361-371.

292

Ikediobi, O., 1989: Industrial malting of sorghum in Nigeria. Paper presented to the ICRISATWASIP-IAR Workshop on Industrial Utilization of Sorghum, held in Kano, Nigeria.

Hoff, J.E.; Singleton, K E., 1977: A method for the determination of tannin in food. Journal of Food Science 42, 6-7.

Longe, K.; Ogedengbe, A., 1989. Influence of fibre on metabolizable energy of diets and performance of growing pullets in the tropics. British Poultry Science 30, 1193-1195.

Mariscal-Landı'n, G.; Avellaneda, J. H.; Reisde Souza, T.C.; Aguilera, A.; Borbolla, G.A.; Mar B., 2004: Effect of tannins in sorghum on amino acid ileal digestibility and on trypsin and chymotrypsin activity of growing pigs. Animal Feed Science and Technology 117, 245264.

NRC, 1994: Nutrient Requirements of Poultry, 9th edition. National Academic of Sciences,

Oduguwa, O. O.; Fanimo, A. O.; Oduguwa, B. O.; Iyayi, E. A.; Opadotun, A. I., 2001: Effect of enzyme supplementation on the nutritive value of MSP in the rat. Tropical Journal of Animal Science 4 (1), 189-195.

Oduguwa, O. O.; Pirgozliev, V.; Acamovic, T., 2007: Energy metabolisability and digestibility of amino acids by broilers fed on malted sorghum sprouts supplemented with polyethylene glycol, charcoal, phytase and xylanase. British Poultry Science 48 (1), 55-63. 
Oke, 2010: Response of turkeys fed diets containing MSP supplemented with enzyme and or yeast. PhD Thesis. Department of Animal Nutrition. Federal University of Agriculture Abeokuta Nigeria.

313 Oso, A. O.; Olusoga Oso, A.; Bamgbose, A. M.; Eruvbetine, D., 2010: Utilization of unpeeled cassava (Manihot esculenta) root meal in diets of weaner rabbits. Livestock Science 127,

Parks, C.W.; Grimes, J. L.; Ferket, P.R.; Fairchild, A.S., 2001: The effect of mannan 192-196.

319 Petersen, D.; Wiseman, J.; Bedford, M. R., 1999: Effect of age and diet on the viscosity of the oligosaccharides, bambermycins, and virginiamycin on performance of large white male market turkeys. Poultry Science 80, 718-723.

323 Sibbald, I.R., 1989: Metabolisable energy evaluation of poultry diets. In: Cole, D.J.A., 324 Haresign,W. (Eds.), Recent Developments in Poultry Nutrition. Anchor Press Ltd., Tiptree, $325 \quad$ Essex, p. 26. Users manual. 
331 Zhang, A.W.; Lee, B.D.; Lee, S.K.; Lee, K.W.; An, G.H.; Song, K.B.; Lee, C.H., 2005: Effects of yeast (Saccharomyces cerevisiae) cell components on growth performance, meat quality, and ileal mucosa development of broilers chicks. Poultry Science 84, 10151021. wall degrading enzymes on the performance of growing broilers fed wheat based diets containing different calcium levels. Poultry Science 79, 66-76. 
Table 1. Chemical composition of malted sorghum sprouts (MSP)

\begin{tabular}{ll}
\hline Chemical compositions & Concentration \\
\hline Gross energy $(\mathrm{MJ} / \mathrm{kg})$ & 14.9 \\
*Metabolisable energy $(\mathrm{MJ} / \mathrm{kg})$ & 11.69 \\
Anti-nutritional factors & \\
Dry matter $(\mathrm{g} / \mathrm{kg})$ & 912 \\
Crude protein $(\mathrm{g} / \mathrm{kg})$ & 163.7 \\
Ether extract $(\mathrm{g} / \mathrm{kg})$ & 38.2 \\
Crude fibre $(\mathrm{g} / \mathrm{kg})$ & 107.5 \\
Mineral content & \\
Calcium $(\mathrm{g} / \mathrm{kg})$ & 9.2 \\
Phosphorus $(\mathrm{g} / \mathrm{kg})$ & 11.1 \\
Fibre fraction & \\
Neutral detergent fibre $(\mathrm{g} / \mathrm{kg})$ & 217 \\
Acid detergent fibre (g/kg) & 147 \\
Acid detergent lignin (g/kg) & 10.3 \\
Gross energy (MJ/kg) & 14.9 \\
Anti-nutritional factors & \\
Hydrocyanide content (mg/kg) & 3.02 \\
Extractible tannin (mg/kg) & 0.09 \\
\hline
\end{tabular}

$355 *$ Metabolisable energy (ME) value of MSP was estimated using NRC (1994), ME $=379 \% \mathrm{CP}$ $356+81.19 \% \mathrm{EE}+35.59 \% \mathrm{NFE}$ 
Table 2. Gross composition (g/kg) of pre-starter (1-28d), starter (28-56d) and grower (28-56d) 360 diets

\begin{tabular}{|c|c|c|c|c|c|c|c|}
\hline \multirow{2}{*}{$\begin{array}{l}\text { Phases of growth } \\
\text { MSP inclusion (g/kg) }\end{array}$} & \multirow{2}{*}{$\begin{array}{l}\text { Pre - } \\
\text { starter } \\
\text { Diets }\end{array}$} & \multicolumn{3}{|c|}{ Starter diets } & \multicolumn{3}{|c|}{ Grower diets } \\
\hline & & 0 & 50 & 100 & 0 & 50 & 100 \\
\hline \multicolumn{8}{|l|}{ Feed ingredients } \\
\hline Maize & 430 & 425 & 425 & 425 & 505 & 505 & 505 \\
\hline Soybean meal & 412 & 240 & 240 & 240 & 180 & 180 & 180 \\
\hline Full fat soybean & - & 100 & 100 & 100 & 80 & 80 & 80 \\
\hline Fish meal & 80 & 80 & 80 & 80 & 60 & 60 & 60 \\
\hline Vegetable oil & - & - & - & - & 20 & 20 & 20 \\
\hline Wheat offal & - & 100 & 50 & - & 100 & 50 & - \\
\hline MSP & - & - & 50 & 100 & - & 50 & 100 \\
\hline Bone meal & 45 & 30 & 30 & 30 & 30 & 30 & 30 \\
\hline Oyster shell & 20 & 14 & 14 & 14 & 14 & 14 & 14 \\
\hline Lysine & 1 & 1.5 & 1.5 & 1.5 & 1.5 & 1.5 & 1.5 \\
\hline Methionine & 4 & 2 & 2 & 2 & 2 & 2 & 2 \\
\hline Premix $\dagger$ & 5 & 5 & 5 & 5 & 5 & 5 & 5 \\
\hline Common salt & 2.5 & 2.5 & 2.5 & 2.5 & 2.5 & 2.5 & 2.5 \\
\hline Total & 1000 & 1000 & 1000 & 1000 & 1000 & 1000 & 1000 \\
\hline \multicolumn{8}{|c|}{ Chemical composition (g/kg) } \\
\hline Dry matter & 900.5 & 910.6 & 908.7 & 911.1 & 902 & 904 & 901 \\
\hline $\mathrm{ME}(\mathrm{MJ} / \mathrm{kg}) \ddagger$ & 11.93 & 12.15 & 12.21 & 12.27 & 12.74 & 12.80 & 12.75 \\
\hline Crude protein & 281.9 & 260.7 & 262.2 & 263.6 & 220.3 & 221.8 & 223.2 \\
\hline Ether extract & 37.6 & 53.7 & 53.4 & 53.0 & 49.5 & 49.2 & 48.8 \\
\hline Crude fibre & 30 & 35.3 & 35.2 & 35.1 & 32.6 & 32.5 & 32.4 \\
\hline Calcium & 21.6 & 15.4 & 15.5 & 15.6 & 11.5 & 11.5 & 15.0 \\
\hline Phosphorus & 8.6 & 6.7 & 6.6 & 6.7 & 6.1 & 6.9 & 6.0 \\
\hline Lysine & 19.1 & 17.7 & 18.1 & 18.6 & 14.3 & 14.7 & 15 \\
\hline Methionine & 8.8 & 6.7 & 6.7 & 6.8 & 6.7 & 6.7 & 6.8 \\
\hline
\end{tabular}

$361 \dagger$ Vitamin/mineral premix provided the following per kg diet (pre-starter and starter diet): $210 \mathrm{~g}$ $362 \mathrm{Ca} ; 85.7 \mathrm{~g} \mathrm{P} ; 828 \mathrm{mg}$ F; $75 \mathrm{mg}$ retinol; $1.25 \mathrm{mg}$ cholecalciferol; $375 \mathrm{mg}$ dl-tocopheryl acetate; $36342.5 \mathrm{mg}$ menadione; $45 \mathrm{mg}$ thiamin; $150 \mathrm{mg}$ riboflavin; $62.5 \mathrm{mg}$ pyridoxine; $300 \mu \mathrm{g}$ 364 cyanocobalamin; $100 \mathrm{mg}$ niacin; $27 \mathrm{mg}$ folic acid; $400 \mathrm{mg}$ pantothenic acid; $12.5 \mathrm{~g}$ choline; 2 365 mg biotin; $45 \mathrm{~g}$ methionine; $2500 \mathrm{mg} \mathrm{Mn} ; 1500 \mathrm{mg} \mathrm{Zn} ; 1250 \mathrm{mg} \mathrm{Fe} ; 250 \mathrm{mg} \mathrm{Cu} ; 15 \mathrm{mg} \mathrm{I} ; 8.2$ $366 \mathrm{mg} \mathrm{Se}$.

$367 \dagger$ Vitamin/mineral premix provided the following per kg diet (grower diet): $200 \mathrm{~g} \mathrm{Ca} ; 77 \mathrm{~g} \mathrm{P} ; 710$ $368 \mathrm{mg} \mathrm{F} ; 42 \mathrm{mg}$ retinol; $1 \mathrm{mg}$ cholecalciferol; $325 \mathrm{mg}$ dl-tocopheryl acetate; $35 \mathrm{mg}$ menadione; 45 $369 \mathrm{mg}$ thiamin; $125 \mathrm{mg}$ riboflavin; $75 \mathrm{mg}$ pyridoxine; $300 \mu \mathrm{g}$ cyanocobalamin; $875 \mathrm{mg}$ niacin; 19 $370 \mathrm{mg}$ folic acid; $300 \mathrm{mg}$ pantothenic acid; $7.5 \mathrm{~g}$ choline; $31 \mathrm{~g}$ methionine; $2500 \mathrm{mg} \mathrm{Mn} ; 1500 \mathrm{mg}$ $371 \mathrm{Zn} ; 1250 \mathrm{mg} \mathrm{Fe} ; 250 \mathrm{mg} \mathrm{Cu} ; 15 \mathrm{mg} \mathrm{I} ; 8.2 \mathrm{mg} \mathrm{Se}$. 
Table 3. Main effect of MSP inclusion levels and supplementation with enzyme or yeast on growth performance of turkeys

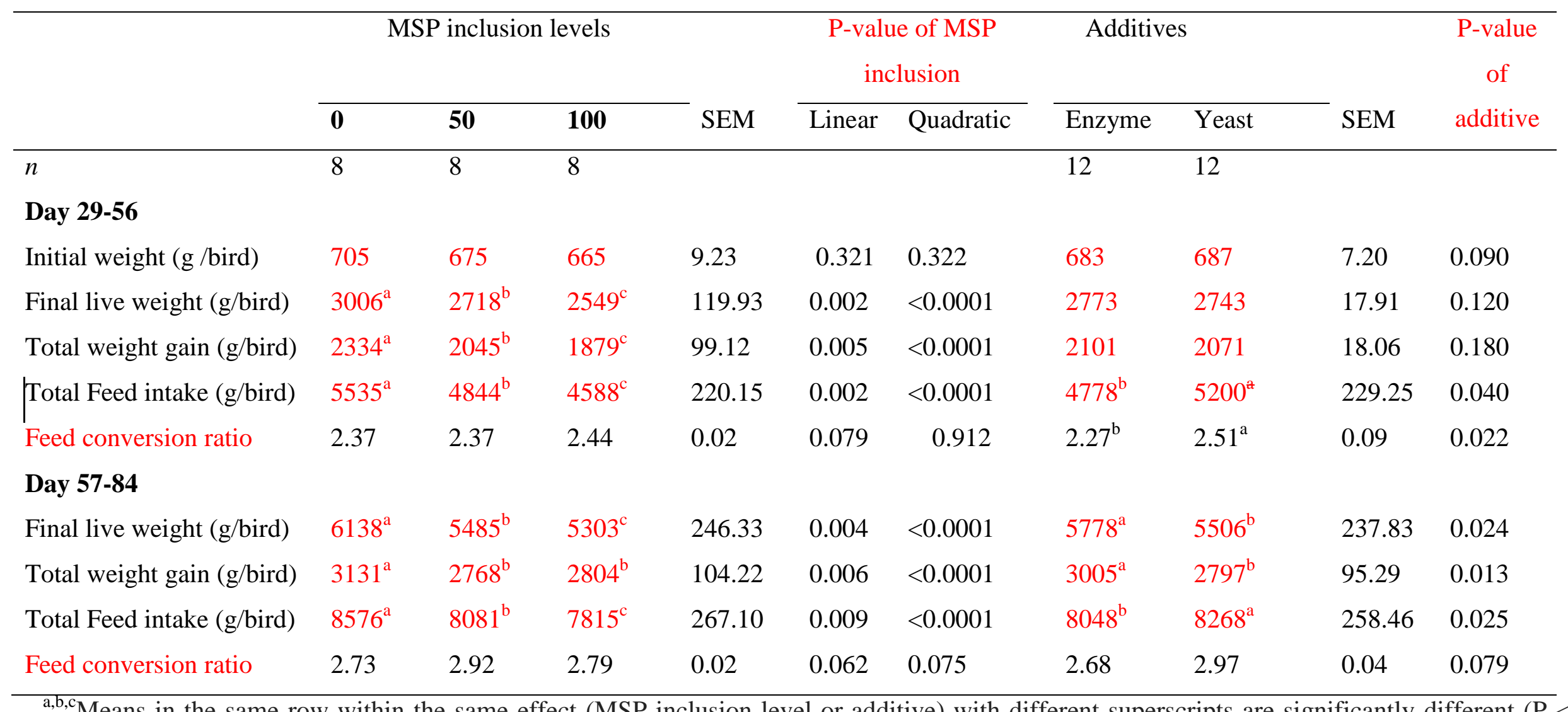

${ }^{\mathrm{a}, \mathrm{b}, \mathrm{c}}$ Means in the same row within the same effect (MSP inclusion level or additive) with different superscripts are significantly different (P $<$ $0.05)$ 
Table 4: Interaction effect of MSP inclusion levels and supplementation with enzyme or yeast on growth performance of turkeys

\begin{tabular}{|c|c|c|c|c|c|c|c|c|}
\hline \multirow[b]{2}{*}{ Measurement } & \multicolumn{3}{|c|}{$200 \mathrm{mg} / \mathrm{kg}$ enzyme } & \multicolumn{3}{|c|}{$200 \mathrm{mg} / \mathrm{kg}$ yeast } & \multirow[b]{2}{*}{ SEM } & \multirow[b]{2}{*}{ P-Value } \\
\hline & 0 & 50 & 100 & 0 & 50 & 100 & & \\
\hline$N$ & 4 & 4 & 4 & 4 & 4 & 4 & & \\
\hline \multicolumn{9}{|l|}{ Day 29-56 } \\
\hline Initial weight (g/bird) & 675 & 670 & 670 & 670 & 675 & 670 & 7.55 & 0.150 \\
\hline Final live weight (g/bird) & $3008^{\mathrm{a}}$ & $2725^{\mathrm{b}}$ & $2585^{\mathrm{c}}$ & $3005^{\mathrm{a}}$ & $2710^{\mathrm{b}}$ & $2513^{\mathrm{c}}$ & 135.01 & 0.020 \\
\hline Total weight gain (g/bird) & $2333^{\mathrm{a}}$ & $2055^{\mathrm{b}}$ & $1915^{\mathrm{c}}$ & $2335^{\mathrm{a}}$ & $2035^{\mathrm{b}}$ & $1842^{\mathrm{d}}$ & 101.29 & 0.040 \\
\hline Total feed intake (g/bird) & $5535^{\mathrm{a}}$ & $4572^{\mathrm{d}}$ & $4230^{\mathrm{e}}$ & $5540^{\mathrm{a}}$ & $5115^{\mathrm{b}}$ & $4940^{c}$ & 245.47 & 0.010 \\
\hline Feed conversion ratio & $2.37^{\mathrm{b}}$ & $2.22^{\mathrm{b}}$ & $2.21^{\mathrm{b}}$ & $2.41^{\mathrm{b}}$ & $2.51^{\mathrm{a}}$ & $2.68^{\mathrm{a}}$ & 0.09 & 0.025 \\
\hline \multicolumn{9}{|l|}{ Day 57-84 } \\
\hline Final live weight (g/bird) & $6175^{\mathrm{a}}$ & $5675^{\mathrm{b}}$ & $5483^{\mathrm{c}}$ & $6100^{\mathrm{a}}$ & $5295^{\mathrm{d}}$ & $5123^{\mathrm{e}}$ & 235.51 & 0.022 \\
\hline Total weight gain (g/bird) & $3168^{\mathrm{a}}$ & $2950^{\mathrm{b}}$ & $2894^{\mathrm{b}}$ & $3095^{\mathrm{ab}}$ & $2585^{\mathrm{d}}$ & $2710^{\mathrm{c}}$ & 130.12 & 0.020 \\
\hline Total feed intake (g/bird) & $8543^{\mathrm{a}}$ & $7965^{\mathrm{c}}$ & $7635^{\mathrm{d}}$ & $8610^{\mathrm{a}}$ & $8198^{b}$ & $7995^{\mathrm{c}}$ & 266.61 & 0.012 \\
\hline Feed conversion ratio & 2.70 & 2.70 & 2.64 & 2.79 & 3.17 & 2.95 & 0.04 & 0.073 \\
\hline
\end{tabular}


Table 5. Main effect of malted sorghum sprout (MSP) inclusion and supplementation with enzyme or yeast on apparent nutrient digestibility, metabolisable energy values and intestinal viscosity of growing turkeys

\begin{tabular}{|c|c|c|c|c|c|c|c|c|c|c|}
\hline & \multicolumn{3}{|c|}{ MSP inclusion levels } & \multirow[b]{2}{*}{ SEM } & \multicolumn{2}{|c|}{ P-value } & \multicolumn{2}{|c|}{ Additives } & \multirow[b]{2}{*}{ SEM } & \multirow[b]{2}{*}{ P-value } \\
\hline & 0 & 50 & 100 & & Linear & Quadratic & Enzyme & Yeast & & \\
\hline \multicolumn{11}{|c|}{ Apparent nutrient digestibility (\%) } \\
\hline $\mathrm{N}$ & 16 & 16 & 16 & & & & 24 & 24 & & \\
\hline Dry matter & $69.79^{\mathrm{b}}$ & $69.86^{\mathrm{b}}$ & $77.32^{\mathrm{a}}$ & 5.99 & 0.029 & 0.042 & 73.41 & 71.23 & 1.48 & 0.095 \\
\hline Crude protein & $69.89^{\mathrm{b}}$ & $69.75^{\mathrm{b}}$ & $73.99^{\mathrm{a}}$ & 5.61 & 0.040 & 0.022 & 71.48 & 70.94 & 1.97 & 0.100 \\
\hline Crude ash & $84.57^{\mathrm{a}}$ & $82.23^{\mathrm{b}}$ & $80.80^{\mathrm{c}}$ & 4.79 & 0.037 & 0.060 & 82.87 & 82.07 & 1.21 & 0.077 \\
\hline $\mathrm{NDF}$ & 64.46 & 64.49 & 64.52 & 1.63 & 0.642 & 0.589 & 64.35 & 64.96 & 1.22 & 0.070 \\
\hline $\mathrm{ADF}$ & 43.13 & 44.90 & 47.35 & 1.02 & 0.084 & 0.229 & 44.70 & 45.56 & 1.08 & 0.075 \\
\hline ADL & 34.65 & 37.86 & 40.10 & 1.18 & 0.065 & 0.166 & 36.78 & 38.29 & 1.02 & 0.090 \\
\hline \multicolumn{11}{|l|}{ Metabolisable energy value } \\
\hline $\mathrm{N}$ & 16 & 16 & 16 & & & & 24 & 24 & & \\
\hline $\operatorname{AME}(\mathrm{MJ} / \mathrm{kg})$ & 15.73 & 16.15 & 16.48 & 0.69 & 0.064 & 0.060 & 16.16 & 16.07 & 0.21 & 0.105 \\
\hline Intestinal viscosity (mPas) & $216.2^{\mathrm{b}}$ & $222.6^{\mathrm{b}}$ & $230.5^{\mathrm{a}}$ & 9.52 & 0.021 & 0.019 & $218.3^{\mathrm{b}}$ & $227.8^{\mathrm{a}}$ & 9.83 & 0.035 \\
\hline $\mathrm{N}$ & 8 & 8 & 8 & & & & 12 & 12 & & \\
\hline
\end{tabular}

${ }^{\mathrm{a}, \mathrm{b}, \mathrm{c}}$ Means in the same row within the same effect (MSP inclusion level or additive) with different superscripts are significantly different $(\mathrm{P}<0.05)$

$\mathrm{NDF}=$ Neutral detergent fibre

$\mathrm{ADF}=$ Acid detergent fibre

$\mathrm{ADL}=$ Acid detergent lignin

$\mathrm{AME}=$ Apparent metabolisable energy 
Table 6. Interaction effect of malted sorghum sprout (MSP) inclusion and supplementation with enzyme or yeast on apparent nutrient digestibility, metabolisable energy values and intestinal viscosity of growing turkeys

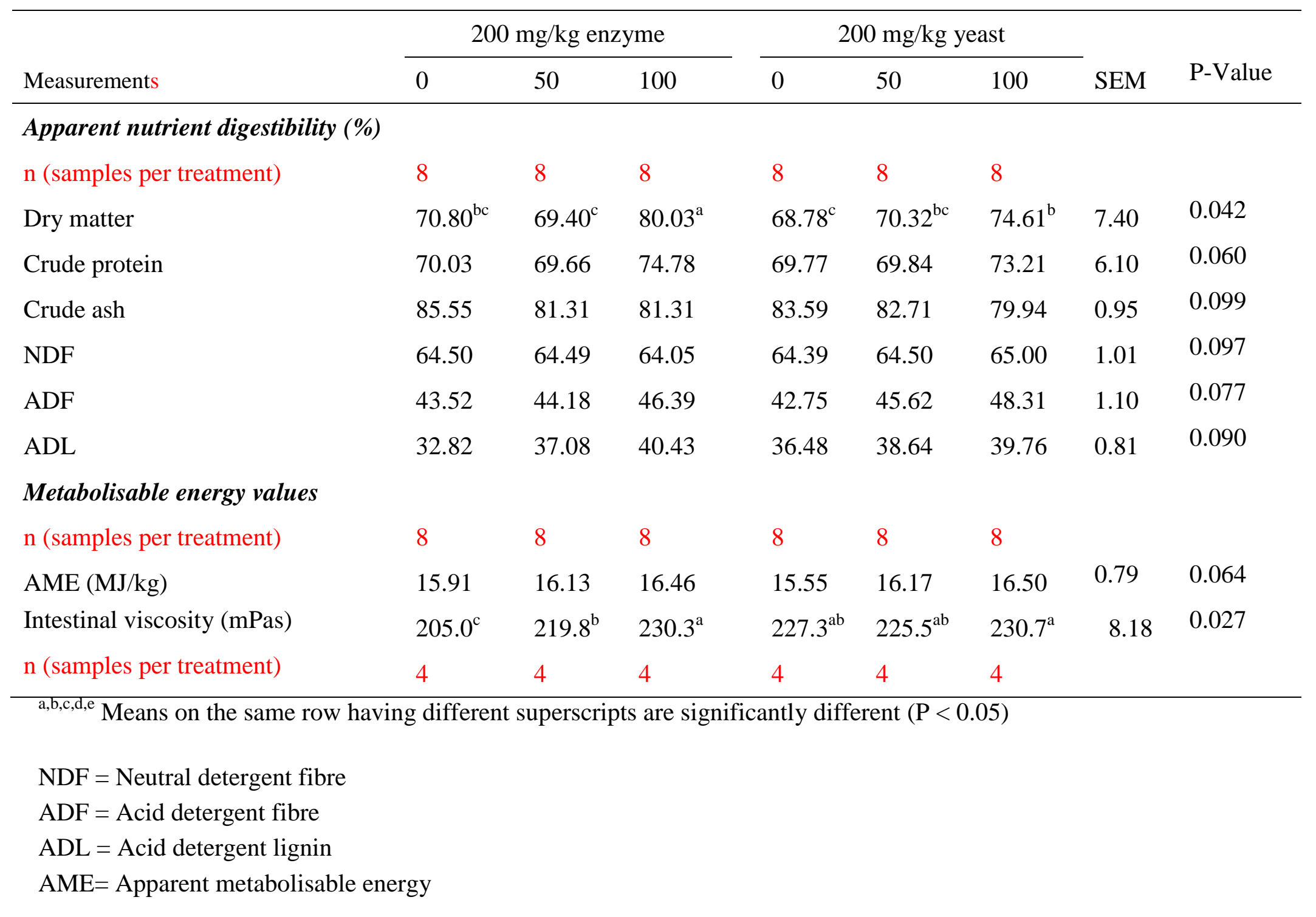

